\title{
Effectiveness of selected strains of entomopathogenic nematodes in peat substrate in container breeding
}

\author{
Joanna Matuska-Łyżwa \\ Faculty of Mathematics and Science, Institute of Biology, Department of Zoology and Biological Didactics, \\ The Jan Kochanowski University in Kielce, \\ Świętokrzyska 15, 25-406 Kielce, Poland \\ e-mail: joannaujk@op.pl
}

\begin{abstract}
Pest control in urban green areas is particularly difficult due to the limitation of pesticide use. Using efficient methods for biological control of herbivores there may be a good solution. Planting plants growing in the forest container breeding have a better growth and better root system comparing to the seedlings produced in traditional forest nurseries. Such plants are not subject to significant shock when replanted, however, they are still exposed to pests living near plantings.

Our research assessed using entomopathogenic nematodes to be introduced into the soil used for plantings in order early protect seedlings against their pests. Nematodes isolated from the natural environment as well as, for control samples, from biopreparations were used in the study. The research was conducted on the soil substrate in containers with seedlings. During the experiment were taken the following parameters: insect mortality, nematode invasion extensity, migration time of invasive larvae, number of migrating larvae, and their survival.The results showed that entomopathogenic nematodes isolated from various provinces in Poland were effective, but characterized by a diverse insecticidal activity in a peat substrate.
\end{abstract}

Key words: entomopathogenic nematodes, Steinernema feltiae, Steinernema kraussei, Galleria mellonella, Owinema, Nemasys L.

\section{Introduction}

The soil fauna, its number and activity are greatly correlated with the anthropopressure level at certain area. Higher urbanization decrease the species diversity at certain area. It has the adverse effect on the matter cycle in the ecosystems, it disturbs natural food chain and contributes to the development of plant pests.

Pest control is very difficult particularly in such types of environment as urban green areas mainly due to the limited use of chemical agents. Therefore, determining natural methods for herbivores control will allow to produce the same results as chemical agents do, at the same it will allow to avoid adverse effects on the environment. The literature provides information on using fungi, viruses, parasitoids and entomopathogenic nematodes for biologi- cal pest control. However, in practice only some of them are satisfactory effective.

Some developmental stages of many insect pests occur in soil. The same environment is inhabited by entomopathogenic nematodes which complete most of their life cycle in insects body cavity. Those nematodes are in symbiosis with the bacteria highly pathogenic to insects. Once nematodes enter host body cavity, they release symbiotic bacteria from its intestine which multiply until they kill insect (Adams et al. 2006). The products of insect tissue disintegrated by bacteria as well as debris provide food for developing generations of entomopathogenic nematodes. Upon depletion of food resources, infective juveniles of entomopathogenic nematodes emerge from a host cadaver and enter the soil in search of fresh insect hosts (Burnell \& Stock 2000). Entomopathogenic nematodes have great potential for use as biological control agents insect pests 
due to highly effective mass production of invasive larvae, its survival stadium, which allows to prepare bio-pesticide and its storage. Increasing efficiency may allow for not only applying races or isolates derived from the local populations as they are better adapted to the local conditions but also selecting relevant application time.

In Poland, in order to renew, afforest or rebuild tree stand are used seedlings with covered root system. They are produced in forest container breeding as they grow better there and have better root system comparing to the seedlings produced in traditional forest nurseries. Such plants are not subject to significant shock when replanted, however, they are still exposed to pests living in plantings area (Szabla \& Pabian 2003).

The aim of our study was to evaluate the effectiveness of some strains of entomopathogenic nematodes introduced into the soil of plantings in order to early protect seedlings against their pests.

\section{Materials and methods}

The research was conducted from 2006 to 2012. Nematodes isolated from their natural environment and, as control samples, nematodes from commercial biopesticides (Owinema - Steinernema feltiae and Nemasys L - S. kraussei) were used in the research. The naturally-obtained nematodes were isolated from soil situated in six Polish provinces. The soil samples, for nematodes isolation, were taken by Egner's probe at the depth of $25 \mathrm{~cm}$ from forest, meadow and arable sites (Table 1).

The soil samples were placed in containers (ca. $500 \mathrm{~cm}^{3}$ ) along with larvae of trap insect Galleria mellonella L. weighting $166 \mathrm{mg}$ (10 insect larvae per a container) and incubated in the thermostatic cabinets at $23^{\circ} \mathrm{C}$ for 16 days (Bedding \& Akhurst 1975; Fan \& Hominick 1991). Every second day, dead insects were isolated and replaced with fresh living ones. Infected larvae were placed on the migratory sponges and stored at temperature of $23^{\circ} \mathrm{C}$ for the time necessary to obtain nematode larvae. Once nematodes left the host cavity, they were regularly picked up to tissue culture bottles and stored at $4^{\circ} \mathrm{C}$. Isolated nematodes were subject to species identification (morphometric measurements), then PCR reaction products were sequenced against primers of genes coding RNA S. feltiae and S. kraussei (Nguyen \& Hunt 2007).

Nematode larvae isolated from the soil and nematodes from the bio-pesticides were used for research conducted on the soil substrate placed in containers with plant cutting for plantings.

Nematode larvae were introduced into the substrate with seedlings. Each isolate of nematodes was introduced into peat substrate with five seedlings in $300 \mathrm{~cm}^{3}$ pots. Some 300 nematode larvae suspended in the aqueous solution were added to each pot. After two months of introducing nematodes to the substrate, one fresh living larva of test insect was added to each pot to confirm presence of nematodes and to recover them. After 5 days, the insects infected by nematodes were placed on the migratory sponges in order to obtain nematode larvae. Migrating larvae were collected to bottles and then stored at $4^{\circ} \mathrm{C}$ in order to check survival of nematodes which preceding generation was living in peat substrate.

For the entire research time, the containers with seedlings were situated at the experimental plot.

During the experiment the following parameters were taken: insect mortality, nematode invasion extensity, migration time, number of migrating larvae, and their survival.

Table 1. Origin of nematode isolates under study

\begin{tabular}{|c|c|c|c|c|c|c|}
\hline No. & Sample number & Site & Province & Type of environment & Longitude & Latitude \\
\hline 1 & 66 & Wólka Wytycka & Lubelskie & meadow & $23^{\circ} 11^{\prime} 21^{\prime \prime}$ & $51^{\circ} 26^{\prime} 27^{\prime \prime}$ \\
\hline 2 & 79 & Sieniec & Łódzkie & field & $18^{\circ} 40^{\prime} 34^{\prime \prime}$ & $51^{\circ} 14^{\prime} 24^{\prime \prime}$ \\
\hline 3 & 80 & Sieniec & Łódzkie & meadow & $18^{\circ} 40^{\prime} 36^{\prime \prime}$ & $51^{\circ} 14^{\prime} 24^{\prime \prime}$ \\
\hline 4 & $130 \mathrm{a}$ & Jodłowiec & Łódzkie & forest & $18^{\circ} 42^{\prime} 15^{\prime \prime}$ & $51^{\circ} 14^{\prime} 47^{\prime \prime}$ \\
\hline 5 & 238 & Stradomia Wierzchnia & Dolnośląskie & meadow & $17^{\circ} 37^{\prime} 07^{\prime \prime}$ & $51^{\circ} 16^{\prime} 09^{\prime \prime}$ \\
\hline 6 & 240 & Skarżysko-Kamienna & Świętokrzyskie & meadow & $20^{\circ} 54^{\prime} 49^{\prime \prime}$ & $51^{\circ} 07^{\prime} 10^{\prime \prime}$ \\
\hline 7 & 247 & Sokolniki & Opolskie & forest & $17^{\circ} 44^{\prime} 01^{\prime \prime}$ & $50^{\circ} 40^{\prime} 02^{\prime \prime}$ \\
\hline 8 & 274 & Rudniki & Śląskie & forest & $19^{\circ} 26^{\prime} 41^{\prime \prime}$ & $50^{\circ} 31^{\prime} 08^{\prime \prime}$ \\
\hline 9 & 267 & Klonów & Świętokrzyskie & forest & $20^{\circ} 49^{\prime} 22^{\prime \prime}$ & $50^{\circ} 56^{\prime} 18^{\prime \prime}$ \\
\hline
\end{tabular}


The migration time of larvae was measured from the moment when first larva emerged from the insect cadaver until the day there were no more larvae on the dish and larvae survival was tested within two and four weeks of migration completion.

For the statistical analysis used analysis of variance of one variable (ANOVA). The experiment was repeated twice.

\section{Results and discussion}

Larvae of entomopathogenic nematodes were isolated from tested soil samples. Based on the results of morphometric measurements and DNA analysis, it was determined that they belong to two species. S. feltiae was isolated from 8 soil samples and $S$. kraussei from one soil sample (Table 2).

Some $64 \%$ of nematode isolates previously introduced into peat substrate were recovered in the research (Table 3 ).

The analysis of invasion extensity shown that in $45 \%$ of bioassays, it was the same as insect mortality. Test insects survived contact with nematodes in three bioassays, in one bioassay they died of other unknown causes. The highest invasion extensity was recorded in the bioassay of nematodes isolated from the sites in the Dolnośląskie Prov-
Table 2. Species isolated from soil samples

\begin{tabular}{|l|c|c|}
\hline No. & Soil number & Species \\
\hline 1 & 66 & Steinernema feltiae \\
\hline 2 & 79 & S. feltiae \\
\hline 3 & 80 & S. feltiae \\
\hline 4 & $130 \mathrm{a}$ & S. feltiae \\
\hline 5 & 238 & S. feltiae \\
\hline 6 & 240 & S. feltiae \\
\hline 7 & 247 & S. feltiae \\
\hline 8 & 274 & S. feltiae \\
\hline 9 & 267 & S. kraussei \\
\hline
\end{tabular}

ince. This parameter was also higher in comparison to the invasion extensity of nematodes isolated from commercial biopreparation. The migration time of nematode larvae varied from 14 to 33 days. The migration time of nematodes isolated in the Lubelskie Province as well as nematodes originating from the commercial agents was the longest while the migration time of isolates from the Dolnośląskie, Łódzkie, and Świętokrzyskie Provinces was the shortest.

Table 3. The parameters of biological activity of nematodes

\begin{tabular}{|c|c|c|c|c|c|c|c|c|}
\hline$\dot{0}$ & 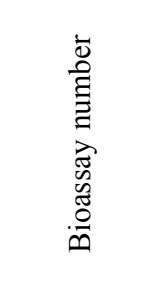 & 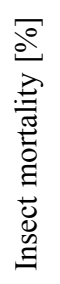 & 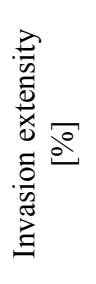 & 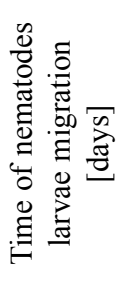 & 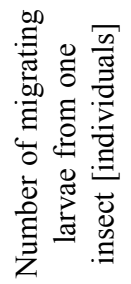 & 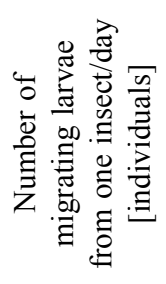 & 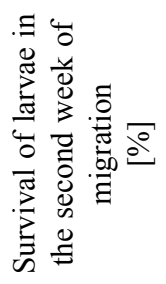 & 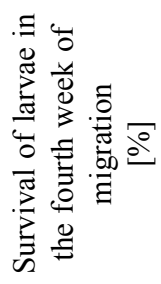 \\
\hline 1 & 66 & 60 & 60 & $33^{c}$ & $4364^{\mathrm{d}}$ & $132^{\mathrm{c}}$ & 100 & 95 \\
\hline 2 & 79 & 40 & 0 & - & - & - & - & - \\
\hline 3 & 80 & 40 & 40 & $14^{\mathrm{a}}$ & $9500^{\mathrm{e}}$ & $677^{\mathrm{e}}$ & 95 & 85 \\
\hline 4 & $130 \mathrm{a}$ & 0 & 0 & - & - & - & - & - \\
\hline 5 & 238 & 80 & 80 & $14^{\mathrm{a}}$ & $3613^{c}$ & $258^{\mathrm{d}}$ & 95 & 75 \\
\hline 6 & 240 & 40 & 20 & $16^{\mathrm{a}}$ & $3450^{c}$ & $215^{\mathrm{d}}$ & 90 & 80 \\
\hline 7 & 247 & 0 & 0 & - & - & - & - & - \\
\hline 8 & 274 & 60 & 20 & $21^{\mathrm{b}}$ & $1870^{\mathrm{b}}$ & $89^{b}$ & 85 & 55 \\
\hline 9 & 267 & 20 & 20 & $19^{\mathrm{b}}$ & $600^{\mathrm{a}}$ & $32^{\mathrm{a}}$ & 85 & 70 \\
\hline 10 & Owinema & 60 & 60 & $31^{\mathrm{c}}$ & $1500^{\mathrm{b}}$ & $48^{\mathrm{a}}$ & 95 & 60 \\
\hline 11 & Nemasys L & 0 & 0 & - & - & - & - & - \\
\hline
\end{tabular}

(different letters in columns denote significant differences at $\mathrm{p}<0.05$ ) 
As to the fertility of nematodes, it was assessed that its number does not depend on its duration. The larvae originating from the Lódzkie Province migrated the most and the least migrating larvae were originating from the Owinema and from the Świętokrzyskie Province (S. kraussei).

The statistical analysis (ANOVA test) was conducted in the reference to ,number of migrating larvae from an insect", it shown significant differences between the control bioassay and $S$. feltiae isolated from the field and between the isolates of $S$. feltiae and S. kraussei originating from the natural environment.

The highest survival of nematodes was observed among larvae from the Lubelskie Province. Additionaly, the lowest decrease in larvae mortality in the four-week storage was recorded in this bioassay as well. The highest number of dead nematodes in the second week of storage was recorded in the bioassay of nematodes isolated in the Świętokrzyskie and Śląskie Provinces, while the same was recorded in the fourth week in bioassay from the Śląskie Province and commercial formulation. Also, among these nematodes (bioassay no. 274 and nematodes from biopreparation) the highest increase in mortality of invasion larvae from the second to fourth week of storage (30 and $35 \%$ respectively) was recorded.

In conclusion, the best invasion parameters were assessed in nematodes of the Dolnośląskie, Lubelskie, and Łódzkie Provinces isolated from meadows and the worst isolates of Śląskie and Świętokrzyskie Provinces ( $S$. kraussei) were caught in forest. Nematodes from commercial agents had moderately high invasion extensity and quite low fertility and survival of larvae migrating from the insect host.

It may be assumed that such commercial agents may be to some extent targeted at pest control, while fertility and at the same time survival of a population in the environment is a side issue.

The studies have shown that, entomopathogenic nematodes isolated from various areas in Poland have a diverse insecticidal activity. The differences in the number of larvae emerging from one insect observed between the bioassays are confirmed by the other studies which demonstrated that the number of infective juveniles may fluctuate from few to few dozen thousand (Mason \& Hominick 1995; Strong et al. 1996). The differences in biology of nematodes isolated from the natural environment was also confirmed by the scientists conducting research on isolates of S. feltiae originating from Spain (Campos-Herrera et al. 2006; Yadav \& Lalramliana 2012).

So far it has been confirmed that nematodes larvae have the highest survival rate and biological activity in sandy and loamy soil where capacity to store water and aeration are optimal for nematodes (Brzeski \& Sandner 1974; Koppenhofer \& Fuzy 2006).
It was also proved that both too low and too high soil moisture are not beneficial to entomopathogenic nematodes. The research shown nematodes swinging like a pendulum on the soil surface have very favourable conditions to invade at moisture ranging from 25 to $40 \%$. Their biological activity declines when moisture is over 50\% (Kaya 1990). According to Grant and Villani (2003) virulence of entomopathogenic nematodes at low moisture may be restored by soil rehydratation. Watering frequently and abundantly peat substrate in this research might have resulted not only in mechanical washing out, but also it might have increased nematodes mortality due to insufficient oxygen conditions. Yet regardless such unfavourable conditions, tested isolates of nematodes confirmed efficient biological activity.

The differences in activity observed between certain bioassays may have resulted from adapting to certain environment they were originating from. Nematodes isolated from meadows were better adapted to moistured peat substrate than nematodes isolated from forest soil. The surface layers of meadow soil where entomopathogenic nematodes usually occur due to the presence of turf, they keep moisture longer than forest soil rich in humus. Higher moisture than in the forest soil, hence more favourable impact of meadow soil environment on fauna diversity and density was also observed by other scientists (Marko-Worłowska \& Chrzan 2010).

The researches conducted so far on the use of entomopathogenic nematodes for control of plant pests (Lacey et al. 2006; Shapiro-Ilan et al. 2009; Lacey \& Georgis 2012) and the results of their tests show that entomopathogenic nematodes may be used widely in the tree protection (Dreistadt 2004).

Relatively easy and simple method of introducing nematode larvae into the peat substrate for plantings (spraying substrate surface) and maintaining nematodes viability in the environment (watering plants) may provide high efficacy of used nematodes against pest population. Introducing entomopathogenic nematodes into the substrate with plantings may allow for fighting with pests already at the moment of planting. Additionally, nematode larvae introduced into the substrate are not exposed during planting to sudden changes in the conditions of environment they originally occur.

The research results may trigger large-scale analysis on the use of entomopathogenic nematodes in limiting population of many pests occurring on plants in forests and urban areas. 


\section{References}

Adams B. J., Fodor A., Koppenhofer H. S., Stackebrandt E., Stock S. P. \& Klein M. G., 2006, Biodiversity and systematics of nematode-bacterium entomopathogens, Biological Control: Theory and Applications in Pest Management 37(1): 32-49.

Bedding R. A. \& Akhurst R. J., 1975, A simple technique for the detection of insect parasitic rhabditid nematodes in soil, Nematologica 21: 109-110.

Brzeski M. \& Sandner H., 1974, Zarys nematologii [Outline of nematology], PWN Warszawa: 18-44, 255-256.

Burnell A. M. \& Stock S. P., 2000, Heterorhabdits, Steinernema and their bacterial symbionts - lethal pathogens of insect, Nematology 2: 31-42.

Campos-Herrera R., Escuer M., Robertson L. \& Gutiérrez C., 2006, Morphological and Ecological Characterization of Steinernema feltiae (Rhabditida: Steinernematidae) Rioja Strain Isolated from Bibio hortulanus (Diptera: Bibionidae) in Spain, The Journal of Nematology 38(1): 68-75.

Dreistadt S. H., 2004, Pests of Landscape Trees and Shrubs: An Integrated Pest Management Guide, Agriculture \& Natural Resources, Oakland, California, USA.

Fan X. \& Hominick W. M., 1991, Efficiency of Galleria (Wax moth) baiting technique for recovering infective stages of entomopathogenic rhabdatids (Steinernematidae and Heterorhabtidae) from sand and soil, Review of Nematology 14: 381-387.

Grant J. A. \& Villani M. G., 2003, Soil moisture effects on entomopathogenic nematodes, Environmental Entomology 32(1): 80-87.

Kaya H. K., 1990, Soil Ecology, [in:] R. Gaugler, H. K. Kaya (eds) Entomopathogenic Nematodes in Biological Control, Boca Raton, FL, CRC Press: 93-115.

Koppenhofer A. M. \& Fuzy E. M., 2006, Effect of soil type on infectivity and persistence of the entomopathogenic nematodes Steinernema scarabaei, Steinernema glaseri, Heterorhabditis zealandica and Heterorhabditis bacteriophora, Journal of Invertebrate Pathology 92(1):11-22.

Lacey L. A. \& Georgis R., 2012, Entomopathogenic Nematodes for Control of Insect Pests Above and Below
Ground with Comments on Commercial Production, Journal of Nematology 44(2): 218-225.

Lacey L. A., Arthurs S. P., Unruh T. R., Headrick H. \& Fritts Jr. R., 2006, Entomopathogenic nematodes for control of codling moth (Lepidoptera: Tortricidae) in apple and pear orchards: Effect of nematode species and seasonal temperatures, adjuvants, application equipment, and post-application irrigation, Biological Control 37: 214-223.

Marko-Worłowska M. \& Chrzan A., 2010, Wpływ antropopresji na entomofaunę łąki i lasu w Parku Krajobrazowym w Krakowie Zakrzówku [The impact of anthropopressure on meadow and forest entomofauna in the Landscape Park of Kraków Zakrzówek], Proceedings of ECOpole 4(1): 161-165.

Mason J. M. \& Hominick W. M., 1995, The effect of temperature on infection, development, and reproduction of Heterorhabditids, Journal of Helminthology 69(4): 337-345.

Nguyen K. B. \& Hunt D. J., 2007, Entomopathogenic Nematodes: Systematics, Phylogeny and Bacterial Symbionts, Brill. Leiden-Boston 5: 63-369.

Shapiro-Ilan D. I., Cottrell T. E., Mizell III R. F., Horton D. L. \& Davis J., 2009, A novel approach to biological control with entomopathogenic nematodes: Prophylactic control of the peachtree borer, Synanthedon exitiosa, Biological Control 48: 259-263.

Strong D. R., Kaya H. K., Whipple A. V., Child A. L., Kraig S., Bondonno M., Dyer K. \& Maron J. L., 1996, Entomopathogenic nematodes: Natural enemies of root-feeding caterpillars on bush lupine, Oecologia 108(1): 167-173.

Szabla K. \& Pabian R., 2003, Szkółkarstwo kontenerowe. Nowe technologie i techniki w szkółkarstwie leśnym [Container plant nursery. New Technologies and techniques in forest nurseries], Centrum Informacyje Lasów Państwowych, Warszawa.

Yadav A. K. \& Lalramliana, 2012, Soil moisture effects on the activity of three entomopathogenic nematodes (Steinernematidae and Heterorhabditidae) isolated from Meghalaya, India, Journal of Parasitic Diseases 36(1): 94-98. 